\title{
Jutustuste kasutamine Keenia jumalateenistustel
}

\section{Ezekiel B. Alembi}

Religioosse kommunikatsiooni puhul kasutatakse erinevaid tehnilisi võtteid ja stiile. Kasutusel on filmid, kirjandus, laulud ja luuletused ning tants. Religioosse teate verbaalsel edastamisel võib rääkija kasutada vanasõnu, mõistatusi jm. Tänapäeval kasutatakse Keenia kirikutes religioosse sõnumi edastamiseks sageli ka jutustusi, et suurendada sõnumi kvaliteeti ja kvantiteeti.

Käesolevas kirjutises tutvustatakse jutustuse kui religioosse kommunikatsioonivahendi kasutamist Keenia kristlikus kirikus. Pearõhk on asetatud jutustuste päritolule ja põhjusele, miks ja kuidas neid on kasutatud.

\section{Jutustuste päritolu}

Kristlus hakkas Keenias levima lääne poolt tulevate misjonäride eduka töö tulemusena, kuid paljud neist ei pidanud lugu Aafrika põlistest traditsioonidest. Varased misjonärid eriti püüdsid ära keelata selliseid üldtuntud kombeid, nagu ümberlõikamine, lastele nime andmise tseremoonia, matuseriitused ja juttude jutustamine. Neid tavasid peeti barbaarseteks ja jumalakartmatuteks (vt P'Bitele'i African Religion in Western Scholarship ja Mbiti African Philosophy and Religion).

Pärast iseseisvuse saavutamist iseseisvus enamik Keenia kirikutest, mille järel algas Aafrika kultuuri sulatamine lääne religiooni, kirikutes hakati kasutama läänemaailmas levinud kirikulaule ja piiblitekst varustati arusaadavust kergendavate viidetega. Religioossete teemade mõistmiseks võeti nende juures kasutusele Aafrika laulud, tantsud, muusikainstrumendid, vanasõnad ja jutustused.

Seega kasutati jumalateenistustel jutustusi kolmel põhjusel.

Esimene neist põhineb juutide taval kasutada piiblit suhtlemisel. Sellele on eeskujuks viis, mida Jeesus kasutas rahva õpetamiseks. Piibel sisaldab märkimisväärselt suure hulga vanasõnu, mõistatusi, mõistujutte, laule ja jutustusi. Neid kasutati eelkõige rõhutamaks inimese loomist, langemist ja päästmist.

Teiseks põhjuseks on Aafrika ajalugu. Nimelt kasutatakse Aafrikas kommunikatsiooniks suurel arvul erinevaid folklooriliike, nagu mõistatused, vanasõnad, laulud, tantsud, jutustused. Seda ei tehta eesmärgitult, vaid sõnumi efektiivsemaks edastamiseks.

Kolmandaks põhjuseks on kaasaegne elukorraldus. Hoolimata kommunikatsioonitehnoloogia arengust, kasutatakse siiski ka vanu suhtlemisviise, mis on palju efektiivsemad ja täpsemad. Keenia kirikud ei ole erandlikud rahvajuttude kasutamise poolest. Jutud on hädavajalikuks vahendiks sõnumi paremaks edastamiseks.

\section{Miks kasutatakse rahvajutte kristliku maailmavaate edastamiseks?}

Jutustused ilmestavad kristlikku temaatikat ja neid kasutatakse, sest

a) nad on publikule tuttavad, kuid nõuavad samas vaeva lahtimõtestamisel;

b) nende lühidus aitab sõnumist paremini aru saada;

c) nad on täpsed ja efektiivsed teate paremaks edastamiseks;

d) nad kasutavad erinevaid anonüümseid karaktereid, mis koguduse poolt lahti 
mõtestatakse; hoolimata sellest, et tegelasteks on enamasti loomad (vahel ka inimesed), on eesmärgiks, et kogudus saaks järeldused teha oma isikliku elu ja religioosse arusaamise järgi;

e) nad teevad jutluse humoorikamaks;

f) nad panevad kuulajaskonna/koguduse põhjalikumalt mõtlema ja suunavad järeldusi tegema.

\section{Kuidas kasutatakse jutustusi religioosses kommunikatsioonis?}

Jutluse pidamisel kombineerib jutlustaja pühakirja lugemise rahvajuttude jutustamisega. Näiteks loeb ta lõigu ja räägib siis jutu, liigub siis jälle tagasi pühakirja juurde ja interpreteerib selle abil jutustuse.

Teine võimalus on rääkida esmalt jutt ja siis lugeda pühakirja osa, mis on lähedaselt seotud jutustuse sõnumiga. Sõnum edastatakse paralleelselt nii pühakirja kui jutustuse abil.

Põhiolemuselt pole pühakirja seletamiseks jutustustes kohta. Neid esitatakse vaid siis, kui kirikuõpetaja leiab selle vajaliku olevat. Allpool esitatud näidetest ilmneb, kuidas katoliku ja protestandi vaimulikud on rahvajutte kasutanud.

\section{Tütarlaps ja kuningas}

Kaua aega tagasi elas üks rikas kuningas. Kord otsustas ta külastada naaberriigis elavat kuningat. Ta võttis kaasa oma ihukaitsjad ja ministrid ja asus teele. Tollel maal oli aga võimalik reisida ainult kaamelite seljas. Nii nad siis sõitsid ja sõitsid, kuni kohtasid oma teel tütarlapsi, kes tõid kaevult vett. Nende seas oli ka neiu, kellesse kuningas kunagi armunud oli olnud. Ta kinkis tütarlapsele oma mantli ja vannutas neiut seda igal pool kaasas kandma kui tunnusmärki. Kuningas omalt poolt andis lubaduse, et kui ta tagasi saabub, saadab oma teenrid tütarlapsele järele.

Tütarlapse kaaslased muutusid väga kadedaks. Nad tahtsid kuninga kingitust kasvõi korraks selga proovida, kuid neiu ei lubanud. Aeg möödus, päevadest said nädalad, tütarlaps kandis ustavalt kingituseks saadud mantlit, kuid kuningalt ei tulnud mingit teadet.

Ühel päeval korjates teiste tüdrukutega tule jaoks hagu, märkas ta põõsastikus teda üksisilmi jälgivat ahvi. Neiule tundus, et ahv oligi see, kes talle teate pidi tooma. Ta jäi oma kaaslastest maha ja läks ahvi juurde. Loom tervitas teda ja sõnas, et pole kunagi nii kaunist mantlit näinud. Seepeale jutustas neiu oma loo: kuidas kuningas oli talle mantli kinkinud ja kuidas ta nü̈̈d truult kuningalt teadet ootas. Tütarlast huviga kuulanud ahv palus luba mantlit endale selga proovida.

Neiu oli sellega vastu tahtmist nõus, aga niipea, kui ahv oli mantli enda kätte saanud, hüppas ta puu otsa. Neiu seda asja nii ei jätnud ja ronis ahvile järele, kuid ahv hüppas kõrvalasuva puu otsa 
ja kadus peagi silmist. Õnnetu tüdruk läks koju ja lohutas end mõttega, et kuningas oli kindlasti oma lubaduse unustanud.

Peagi saatis kuningas teele oma ustavad teenrid, kes pidid üles otsima ja kuningakotta tooma neiu, kes kannab mantlit kui kuninga jäetud tunnusmärki. Kui teenrid külla jõudsid, ei suutnud nad kuidagi kuninga armastatut ära tunda, sest kõik tütarlapsed tundusid üksteisega sarnanevat. Neiu seletas küll, et tema oli kuninga väljavalitu, kuid märgi puudumise tõttu teda ei usutud.

Teenrid otsisid kogu küla läbi, kuid neid saatis ebaedu. Seetõttu asusid nad kurvalt koduteele. Teel märkasid nad aga mantlit kandvat ahvi. Nad pü̈̈dsid ta kinni ja viisid kuningakotta.

Selle loo mõtles oma jutluse jaoks välja üks katoliku preester. Kõige parema tulemuse saavutab sellega õige ajastuse puhul. Samuti ilmestab see väga hästi jutlust ning igal juhul on sellest abi unne vajuvate koguduseliikmete ülesäratamisel.

Preester kommenteeris juttu, et juudid ei pääse oma uskmatuse tõttu jumalariiki ning samas on mittejuutidel, kes Jumalasse usuvad, see võimalus olemas (Mt 21:33-45, Mk 12:1-12 ja Lk 20: 9-19).

Preester tuletas ristitutele meelde, et nad sarnanevad Jeesusega ja peavad oma usu püsimajäämise nimel võitlema (Mk 13:33-37).

Kogudusele jutustus meeldis.

\section{Vanaeit ja hü̈̈̈̈n}

Kord pidasid jahimehed jahti hüäänile, kes oli ära söönud ühe külaelaniku lamba.

Odade, vibude ja nooltega relvastatud meeste eest põgenedes jõudis hüäön ühe maja juurde. Kuna maja uks oli lahti, lipsas hüään sisse ja nägi toas vana naist.

"Peida mind voodi alla," palus hüään. "Mind aetakse taga ja tahetakse ära tappa."

Naise meel läks härdaks ning ta lubas hüäänil peitu pugeda.

Peagi jõudsid ka jahimehed majani. Nad nägid vana naist ja küsisid: "Ega sa pole siin ühte hüäöni näinud?»

Naine eitas.

Selle vastuse peale jooksid jahimehed edasi. Kui kõik olid läinud, tuli hüään peidust välja, tappis vana naise ja pistis ta nahka. 
Loo autor on protestantliku kiriku vaimulik ja juttu kasutati sissejuhatuseks jutlusele patustamisest.

See on näide lühikesest ja mõjuvast loost, mis hoiab kuulajad ärksana. Antud loos sümboliseerib hüään pattu ja vana naise surm sümboliseerib tulevikku, mis ootab patustajaid. Hüään ehk hävitaja surmas naise, kes kaitses teda surma eest. Vaimulik seletas kogudusele, et sama saatus ootab ka kõiki patte varjavaid kristlasi. Jahimehi võib samastada vaimulikega, kes jälitavad patustajaid ja võitlevad patu vastu. Preester pani selle looga kristlastele eriti südamele, et nad jagaksid oma probleeme pihiisadega, et mitte hukkuda samamoodi kui vana naine.

\section{Nõid ja printsess}

Elas kord kuningas, kellel oli vaid üks tütar, keda ta väga armastas. Ta soovis, et tütar abielluks kord mehega, kes võiks valitsusohjad riigis enda kätte võtta.

Kuninga külas elas aga kuri nõid, kes printsessi vihkas. Alati püüdis ta leida mooduseid kuningatütre hävitamiseks, kuid seni polnud see veel õnnestunud. Kord kuningalossi ümber hiilides märkas ta toas lauale jäetud kuninga ja printsessi hommikueinet. Nõid hiilis tuppa ja puistas kuningatütre tee sisse mürgitaimi. Vaevalt oli ta toast välja jõudnud, kui tuppa astusid kuningas ja ta tütar ning asusid einestama. Niipea kui printsess oli teed joonud, muutus ta konnaks. Konn hüppas aknast välja otse lossi kõrval asuvasse põõsastikku. Dzhunglis ringi hüpates ja abistajaid otsides jõudis ta oma kodust väga kaugele maale.

Tol maal elas pealik, kel oli üks poeg, kes armastas jahil käia. Tihtipeale võttis ta oma teenritega ette pikki jahiretki dzhunglisse. Ühel päeval taas jahikäigul olles nägi ta oma imestuseks konna, kes tema ümber ringi hüppas. Mehele tundus konn nii kummaline, et ta võttis tolle kaasa. Kodus kutsus isa ta enda juurde ja küsis, mis poeg ka jahilt kaasa tõi. Poeg pidi selle peale oma tühje pihke näitama ning ütlema, et ta leidis vaid ühe konna. Selline ebaõnn pahandas isa ja ta käskis konna ära visata. Poeg läks aga oma tuppa ja hakkas konna lähemalt silmitsema.

Äkitselt hakkas konn rääkima: "Palun ära vii mind tagasi džunglisse. Ma ei suuda seal üksinduses elada. Luba, ma jään su padja alla magama. Ma tasun sulle mitmekordselt." Noormehel hakkas konnast kahju ja ta nõustus teda oma padja alla lubama. Järgmisel hommikul ärgates leidis ta end lebamas imeilusa tütarlapse kõrval.

Neiu rääkis oma minevikust ja küsis, kas noormees ei tahaks temaga koos tagasi tema kodukülla pöörduda. Koos läksid nad vana kuninga juurde, kes tasus noormehele oma tütre ja kuningriigiga. Lisaks sai noormees $k a$ oma kuningriigi valitsejaks ning nad elasid onnelikult oma surmani. 
Jutu autoriks on katoliku preester, kes kasutas juttu hingepäästmise jutluse illustreerimiseks.

Tsiteerides Esimest Moosese raamatut 1:26, tuletas preester kogudusele meelde, et inimene loodi Jumala kuju ja näo järgi ning sai õiguse nautida samu hüvesid, mis Jumalgi. Kuid saatan (keda jutustuses kujutab nõid) oli inimese peale kade ja pettis teda (Kolmas Moosese raamat). Nii kaotas inimene oma õigused ja muutus justkui konnaks. Inimene aeti pagendusse ja ta langes patuellu (mis sarnaneb pimedusega dzhunglis).

Preester rääkis kogudusele, et Jumal armastab maailma nii palju, et saatis oma poja Jeesus Kristuse inimeste eest surema. Jeesus aitas maa peal viibides inimestel oma õige tee üles leida, et saatanal (nõial) poleks nende üle enam võimu. Noormees sümboliseerib ohverdust, mille Jeesus inimkonna heaks tegi - armastas patuseid nii halbade ja roojastena, kui nad on.

Preester osutas ka sarnasusele Jeesuse ravivõimetega - eriti pidalitõbist ravides. Pidalitõbistest hoidsid kaaskodanikud kui katkust eemale. Tänavatel liikudes pidid haiged helistama kellukesi, et oma tulekust märku anda. Konna kätte võtmist ja oma kotti panemist võib samastada pidalitõbise armastamisega ja tema puutumisega (Mt 8:1-4, Lk 5:12-16 ja Mk 1:40-45). Tüdruku poolt antud tasu on sama, mis saab leeprahaige ravija, kes õpetab oma oskusi ka teistele.

Jutustusi saab kasutada nii üldise kui väga kitsa mõtte edasiandmiseks. Keenias kasutavad kristlased seda meetodit Piibli sõnumi lahtimõtestamiseks ning neid lugusid armastatakse nende rahvaläheduse ja humoorikuse tõttu.

Tõlkinud Triin Kurrikoff 